\title{
Finding common ground? Spaces of dialogue and the negotiation of Indigenous interests in environmental campaigns in Australia
}

\author{
Jenny Pickerill
}

Department of Geography, Leicester University, University Road, Leicester, LE1 7RH, UK. tel: 0116252 3836, fax: 0116252 3854, email: j.pickerill@ leicester.ac.uk

[Final submitted draft $29^{\text {th }}$ June 2008]

\begin{abstract}
Critiquing the usefulness of cosmopolitanism this paper argues that we need a more nuanced and subtle understanding of how commonalities are found, created and maintained across difference. This paper uses two juxtapositions of perspective (around place and environment) to explore how such boundaries of difference can be negotiated. It uses an examination of the ways in which environmental groups in Australia have sought to negotiate Indigenous interests through creating spaces of dialogue and changing working practices. It is based on thirty interviews with both Indigenous and non-Indigenous activists across two case regions; Cape York (Queensland) and Barmah-Millewa (Victoria/New South Wales). Four issues were identified that have proved particularly contentious in negotiations to build collaborative campaigns: language; power and ownership; scale and timeframes; and economics. There are examples of both successes and ongoing problematic practices across these tensions. However there is also a growing mutual ownership of the issues. Moving beyond a colonial paternal sense of responsibility, to a dynamic and engaged mutuality of concern for both processes and outcomes has resulted in gradual, small, and progressive steps forward in Indigenous/ nonIndigenous collaborative environmental campaigning.
\end{abstract}

\section{Keywords}

Indigenous, environment, place, country, Australia, responsibility, postcolonialism, dialogue, activism, common ground, land rights, Cape York, Barmah-Millewa

\section{Introduction}

For the sake of this country ... it is imperative that the environmental movement and Indigenous peoples work out the common ground between them, understand where they are both coming from and create forums and networks to work together. (Pat Dodson, former Chairperson of the Council for Aboriginal Reconciliation, 1997)

This paper examines the ways in which environmental groups have sought to negotiate Indigenous interests by creating spaces of dialogue and changing their working practices. It is in the everyday and informal spaces of practice, as Indigenous and non-Indigenous activists seek to work together, that provide clues as how commonalities across difference are built. 
In the search for commonality, cosmopolitanism as both an attitude and a strategy has been developed as a progressive concept that accepts difference. However, cosmopolitanism is critiqued here as inadequate in aiding our understanding of commonality. Thus in contrast, this paper seeks to employ a more nuanced and subtle understanding of 'common ground' that takes greater stock of the importance of examining practices, that more clearly considers the construction of values used in discussions of commonality, and acknowledges the potential of a pluralistic and adversarial politics. In specific relation to Indigenous politics there are two juxtapositions of perspective (around place and environment) which can act as boundaries of difference and thus barriers to working together. The ways in which activists have negotiated these differences signals both optimism for future collaboration and identifies areas that still require further consideration.

This paper's concern for indigeneity is part of a reinvigoration of Indigenous geographies within the discipline (exemplified by Laurie et al., 2005; Howitt, 2001; Howitt and SuchetPearson, 2006, Palmer, 2006, and Porter, 2006). Many geographers are troubled by the discipline's contribution to colonialism and imperialism (see for example Blaut, 1993) and are consequently concerned with "creating anti-colonial geographies" (Johnson et al., 2007, p.118). In particular, geography brings to this work an awareness of place and its centrality in debates of land, justice, identity, and autonomy. In addition, this work sits within the burgeoning literature critiquing dualistic ideas of nature and a concern, particularly within Australia, to acknowledge the complexity of cultural interconnectedness with the environment (Willems-Braun, 1997; Castree and Head, 2007).

As such this work is part of geography's embrace of postcolonial perspectives (Jacobs, 1996, Sidaway, 2000; Gooder and Jacobs, 2000) and the geographies of difference. The use of a postcolonial critique is used less as a chronological moment 'after' colonialism and more as "against the grain of" (Gregory, 2001, p.612), and thus "draws attention to the shadows it still casts over the present" (p.613). Postcolonialism also seeks to disrupt assumptions about categories and identities. The very definition of Indigenous "creates a tangle of ambiguities" (Johnson et al., 2007, p.117). Often applied to those with connections to pre-colonial lands who were then subsumed and dispossessed by colonising powers, its definitional boundaries are contested and fluid. As Shaw et al. note, "bifurcating 'Indigenous' from 'Western' is misleading and problematic" (2006, p.269). Thus, in this paper a distinction is made between Indigenous and non-Indigenous primarily to reflect common usage by those interviewed. This is done acknowledging that there is interdependence, a mutual responsibility that flows in all directions from Indigenous/non-Indigenous interactions which upsets the colonial stereotype and acknowledges the agency and power of Indigenous Australians. Furthermore, 'land' in Indigenous Australian belief system is taken to include sea and coastal areas in contrast to the more restrictive connotations of non-Indigenous perspectives (Jackson, 1995).

\section{The need for common ground}

\section{The limits of cosmopolitanism}

There has long been a concern for the 'geographies of difference' (cf. Harvey, 1996) and a desire to understand the commonalities of human existence. This is due in part to awareness that to celebrate the particular is potentially to support nationalisms and tolerate such horrors as fascism and war. It also fails to acknowledge our interdependence and mutual construction through relations between each other. This has led many geographers, and numerous others, to seek to understand as Touraine (2000) asks 'can we live together?'. Such a question demands that we explore our commonalities. A dominant contemporary approach in social 
sciences in this search for 'common ground' is the concept of cosmopolitanism (Held, 1995; Hannerz, 1996; Beck, 2006). This is both an 'outlook' and a strategy. It offers "the potential for a new kind of tolerance based upon pluralism, dialogue and a recognition of difference" (Savage et al., 2005, p.181). As an attitude it is "an orientation, a willingness to engage with the other" (Hannerz, 1996, p.103), that its proponents argue leads to individuals articulating an awareness and concern for the global and a larger sense of responsibility for 'others'. As a strategy, cosmopolitanism seeks to define moral universals (such as 'rights', 'justice' and 'equality'), but crucially unlike universalism, acknowledges 'otherness' and difference. This approach seeks to find forms of commonality that unite humanity and from which we can build common understandings of how a fair and just world could be.

Although alluring in its acknowledgment of difference while still seeking universals, cosmopolitanism has three main flaws. First, it is "still largely a speculative discourse" (Tomlinson, 2003, p.240) which lacks empirical depth and robust examples of practice. This abstraction leads to a "nongeography of universalism" (Mohan, 2006, p.869) that "can abdicate responsibility for specific care behind a discourse of abstract and universal love" (ibid). For Parekh (2003) this "is too abstract to generate the emotional and moral energy needed to live up to its austere imperatives" (p.12). There is a need to focus on how commonalities are really made rather than on abstract cosmopolitanisms. In examining treatment of Indigenous Australians, Povinelli (2002) talks of the 'cunning of recognition' whereby increasingly, public law and public support attests to Indigenous agency, rights and politics, but that such recognition is not reflected in everyday practices. Second, rather than encouraging engagement with the 'other' it has been critiqued as imposing a Western world view and values upon all (MacIntyre, 1998). Third, Mouffe $(2000,2005)$ argues that if we create space for adversarial politics within the system then antagonistic, violent, or terrorist articulations of power are less likely to occur. Mouffe does not dismiss the benefits of acknowledging commonalities or finding consensus, but insists on a 'conflictual consensus' "consensus on the ethico-political values of liberty and equality for all, dissent about their interpretation" (2005, p.121). We need to create an agonistic pluralism where we accept that differences will always occur and it will not be possible by whatever model to create a unified vision for society.

\section{$\underline{\text { Negotiating boundaries of difference }}$}

We need then a more nuanced and subtle understanding of 'common ground' and how commonalities are found, created and maintained across difference. We can best understand this by exploring practices rather than abstract universalisms. However, these practices do not exist in a neutral vacuum and there are two juxtapositions of perspective (around place and environment) which can act as boundaries of difference ${ }^{1}$. The differing approaches towards

\footnotetext{
${ }^{1}$ There are, of course, many additional differences and contexts that complicate negotiations of common ground, a key factor being the role of the state and legislature (Toyne, 1994). For example, The Environment Protection and Biodiversity Conservation Act 1999 (EPBC Act), which is the key environment and heritage legislation, clearly extends protection to areas which are valued not just for their biodiversity but also cultural places. This allows for the same protection that an area of outstanding natural beauty or biodiversity would have to be applied to areas of cultural value. The fact that they are considered within the same act, given the same protection, and can by implication overlap (i.e. a place can be historic, natural and culturally valuable) suggests an acknowledgement of the interrelationship between environment and cultural. Despite this, however, the Act does not ask us to implicitly understand that most places protected for environmental reasons also have cultural value. It does not create an assumed link between cultural and environmental value.
} 
how 'place' and 'environment' are understood can act as barriers to the building of commonality, and thus need to be navigated and negotiated.

\section{Place}

Understanding how place is important to those seeking 'common ground' is necessary precisely because of its complexity and contestation. Place is both an ontology (defining what exists) and an epistemology (a particular way of seeing) and difference is articulated through both. A relational perspective views place as a social construct in relation to wider social processes and power. This perspective has had most to say about how we deal with assertions of differential geographies. For Harvey (1996) and Massey (1999), in different ways, localism, or the assertion of rights over particular places as being different and thus of value in and of themselves is a regressive view of place that will lead to 'geographical apartheid'. This is because such an understanding of place as discreet or as metaphorical islands fails to acknowledge its relational construction (through translocal linkages).

For Massey, local difference is important but is itself a product of extralocal relations and interactions, thus "specificity (local uniqueness, a sense of place) derives not from some mythical internal roots nor from a history of relative isolation - now to be disrupted by globalisation - but by the absolute particularity of the mixture of influences found together there" (1999, 21-22). She has gone on to argue that we can distinguish between 'progressive' (open, inclusive) and 'regressive' (closed, exclusive) assertions of place by supporting those places that acknowledge place interdependency while also seeking to defend local specificities. In a different way Harvey (1996) argues that while placed-based localisms are parochial, transnational solidarities (even going so far as to advocate the use of universals such as the UN Declaration of Human Rights) between places are progressive because they have understood their inter-place connections. Harvey is also concerned with scaled understandings of place. Thus he argues that by considering the global consequences of localism, what might appear justified at the local scale can be seen to have significant negative ramifications at the global scale.

Castree (2004) and Escobar (2001) both argue that while such a relational perspective is theoretically appealing it fails to acknowledge the reality of the needs of some place-based local movements. Indigenous people worldwide "are struggling for differential geographies: that is, the right to make their own places, rather than have them made for them" (Castree, 2004, p.136). Castree does not dismiss the relational approach per se, but argues that we need a more nuanced understanding of place in order to be able to support some Indigenous people's claims to place. He gives a number of reasons for why Indigenous peoples should be able to make a 'special case', including their history of dispossession and ongoing marginalisation.

Many Indigenous groups do use transnational solidarities (through the global identity of indigeneity), and universalisms (such as the language of 'rights'). However, many use these to assert their demands for full control over particular places (Castree, 2004). They are a mixture of Massey's notion of progressive and regressive places. Castree goes on to claim that as critical geographers we should support the rights of Indigenous people even if that will have costs and implications for the non-Indigenous (contra Harvey) because it is "a politics wherein geographical difference cannot flourish unless bold attempts are made to control the traffic to and from those places Indigenous groups seek control over" (2004, p.163). In other words some projects require that strong boundaries are erected around places. 
Asserting that place is important, and that Indigenous people should be supported in a placebased politics might seem to work against using place as a form of 'common ground'. The impasse in many debates about Indigenous rights to land and sea are that non-Indigenous people also have claims and that such places are produced through multiple layers of histories and connections. This is particularly the case in Australia where determinations of Native Title have been limited, and increasingly, Indigenous communities have dismissed the process as unfair and unproductive (Agius et al., 2007). At the same time some environmental groups support for the creation of protected areas (such as National Parks and World Heritage Areas) and the banning of hunting has been perceived as anti-Indigenous (Langton 1998, 2003). However, Johnson and Murton (2007) argue that we should use this tension and complexity to reconsider place. The non-Indigenous can learn from Indigenous ontology, particularly in placing ourselves back into nature to produce an embodied relationship between humans and nature through which we can all "invest meaning into the landscape" (Johnson and Murton, 2007, p.126). But this is not a simple appropriation of Indigenous perspectives through which we can 'see' place differently; it is a dialogue, "a common desire ... the realisation that, by working together, Indigenous and Western academics both have important understandings to add to our common cause" (Johnson and Murton, 2007, p.126-7). This dialogue is not about readily reaching compromises or necessarily privileging one set of claims over another, but starts by acknowledging its importance to all parties. It acknowledges the complexity of place, different ontologies, and thus ultimately the pluralism of place.

\section{Environment}

The ways in which the environment is understood and valued varies considerably across different cultures. This difference can cause a mutual misunderstanding of the humanenvironment relationship that in turn confuses attempts at finding 'common ground'. There are many academic critiques of the validity of any nature-culture dualism and a growth of work on the hybridity of nature and culture with emerging work considering instead 'socionatures' or 'naturecultures' (see Davison, 2007 for a useful review). Of particular relevance is the work of Willems-Braun (1997) who has detailed the ways in which "First Nations are contesting the buried colonial epistemologies that enframe nature through a defining absence" (p.25) and instead are re-ascribing the social into nature.

While the interdependence of nature/culture is a core rationale in much environmental thought so too is an attachment to the dualistic constructions of wilderness and nature as a sacred 'other'. Thus, as Milton (1999) notes, the contradiction of appreciating the non-dualistic approach while still employing a dualistic one looks set to continue for some time. There are two reasons for this. First, there are those (especially deep ecologists) who argue that a separation of nature from society is necessary in order to clearly identify the causal links of environmental destruction. Second, the emotive power of a sacred experience with nature sustains a belief in its 'otherness'. Thus, "rather than straddling a gulf between nature as spoken and nature as lived, environmentalism rests on an alliance of scientific description of nature and intimate encounter with nature" (Davison, 2007, 10).

Consequently in Australia there is a juxtaposition between non-Indigenous views of the environment as something to be kept apart from humans' interference (while acknowledging humans interconnectedness with it), and Indigenous understanding of environmental and cultural domains as inseparable (Strang, 1997). Non-Indigenous approaches to the environment are often concerned with improving scientific management of particular places to ensure it retains its bio-diversity or landscape value (McGregor, 2004). This approach is further expressed in the language non-Indigenous environmentalists use to articulate the need 
for environmental preservation. Common use of the term 'wilderness' and 'wild' has long been criticised by Indigenous activists as colonial and yet its use continues and signifies the ways in which non-Indigenous activists perceive the environment as a sacred 'other' and 'outthere' beyond everyday life (Rose, 2004; Pickerill, 2008).

Rather than the 'environment', Indigenous Australians talk of 'country'; an intertwining of ancestry, kinship and responsibility (Baker et al., 2001). This country is "multidimensional it consists of people, animals, plants, Dreamings, underground, earth, soils, minerals and waters, surface water, and air" (Rose, 1996, p.8). In addition while Non-Indigenous Australians may see land management as a form of control over resources, an Indigenous perspective is far more about 'caring for country' as a form of reciprocal negotiation with the needs of that particular place (Young et al., 1991). Thus, there is no dualism between environment and culture as they 'are one and the same, they co-exist and are not separate' (Melissa George, a Wulgurukaba woman and traditional owner, quoted in Pickerill, 2008, p.98).

These differences are clear in the debate over Sea Country. While non-Indigenous people tend to conceptualize the sea as a common domain, Indigenous people "view the sea as part of their traditional country with all the possibilities of identity, ownership, private use rights, and management responsibilities that apply to land" (Smyth, 2001, p.60). As a result Indigenous aspirations to own and manage the sea and other waterways have been constrained (Jackson, 1995; Jackson et al., 2005).

However, there are a number of emerging examples of successful strategies through which these differences can be negotiated (Adams, 2004). Walton and Bailey (2005), using the example of wilderness preservation campaigns in Alabama, have illustrated how the nonIndigenous framing of wilderness could be shifted to incorporate their cultural heritage and yet retain the emotional resonance that calls to protect 'wilderness' offers. This broadening remit of concern has also been used by Howitt (2001) who argues that successful resource management has to include four core values; "social justice, ecological sustainability, economic equity and cultural diversity" (p.10). Thus he seeks to adopt an Indigenous approach of "caring for country' that understands the environmental, cultural and economic domains as inseparably intertwined. On a similarly practical level, Agius et al. (2007) consider the importance of the processes of negotiation in reconfiguring a politics of place in South Australia, not just in respecting Indigenous jurisdictions but in shifting discussion away from legalities and focusing instead on relationships and dialogue.

\section{Entangled power relations and methodology}

There are entangled power relations in the ways in which this research was conducted. As Tuhiwai Smith notes "research is not an innocent or distant academic exercise but an activity that has something at stake and that occurs in a set of political and social conditions" (1999, p.5). My positionality as an outsider (as English) and simultaneously as representing a certain form of power (academic, funded by The British Academy, non-Indigenous, participant in The Wilderness Society [TWS]), does little to challenge ongoing unequal power relations. Postcolonial perspectives specifically call on us not only to acknowledge the "politics of production of academic knowledges' (Shaw et al., 2006, p.268) and the languages and assumptions inherent on our work, but also to change our practices. Thus, as problematic as studying Indigeneity can be, it is also a vital part of conducting research that is "concerned with breaking, and writing, the silences of the present as well as the past" (Gilmartin, 2002, p.35). 
Research must be sensitive to these power relations in its practice. However, as it stands, this research did not untangle or subvert many power inequities, and was conducted to challenge existing silences, rather than developed in collaboration with Indigenous activists (as advised by AIATSIS, 2000). In other words the research was not reciprocal ${ }^{2}$. The material was collated through a rather extractive and short-term form of engagement through interviews during a three-month visit in the Australian winter of 2005. This work is intended as the beginning of a longer engagement and thus although the stories told through it need to be written, they need to be done so in acknowledgement of the problematic nature of some of its methodological context and are written here as beginnings of longer stories rather than as foreclosed arguments.

Material was collated through thirty in-depth interviews with activists, a third of whom selfidentified as Indigenous ${ }^{3}$. Data collection focused on two case study regions: Cape York (Queensland) and Barmah-Millewa (Victoria/ New South Wales). Both of these areas are the focus of ongoing environmental campaigns and Indigenous demands for recognition of their rights and return of land to their control. However, these regions are quite different in scale, location, history, and the types of environmental organisations involved in the campaigns.

The term 'activist' is applied broadly in this paper to include all those who were involved in environmental campaigns. For non-Indigenous interviewees that included small grassroots groups such as Friends of the Earth (Melbourne), or national organisations such as TWS, as well as mainstream corporate-funded organisations such as $\mathrm{WWF}^{4}$. There is clearly much differentiation between such groups in their politics, organisation, and ambition. In particular there are a number of historical tensions between past acts and misunderstandings between Indigenous people and environmental organisations often concerning dispossession of land for environmental protection, and these shape how different groups are now received (Adams and Mulligan, 2003; Peet and Watts, 1996).

Indigenous interviewees included community leaders, and those working for Indigenous Development Corporations and with Indigenous environmental alliances. Many perceived themselves to be environmentalists; or rather that environmental concern was a core part of their Indigenous identity (though often neither more or less important than other aspects). However, their assertive articulation of this concern (evident in their activism and rhetoric) tended to identify them to others, especially non-Indigenous activists, as being useful contacts ('middle people') through which to build relationships with others (often broader Indigenous

\footnotetext{
${ }^{2}$ While not necessarily reciprocity, two forms of engagement continued after the completion of the data collection. First, a calendar was produced by the author from her photographs of Australia. The 2007 'Caring for Country' calendar was designed to publicise the ways in which Indigenous rights, environmental knowledge and approaches to land management continue to be marginalised. It raised $£ 600$ for Indigenous organisations running Caring for Country projects in Australia. Second, the author arranged for Dr Wayne Atkinson, a Yorta Yorta man to come to Leicester University to give a seminar about Barmah-Millewa and Indigenous land justice (Atkinson, 2006).

${ }^{3}$ Secondary material was collated from Australian University archives, Indigenous organisations and their records, public museums and state libraries, environmental organisations' libraries and Indigenous autobiographies.

${ }^{4}$ Including WWF under such a definition might seem like an anomaly given its international remit and structure that makes it less an activist organisation and more a formal NGO. In Cape York it deliberately sought to avoid politics, concentrating on funding small-scale species conservation projects, however it is included here as Indigenous interviewees often evoked it as an example of best practice, and this it needs considering alongside other more explicitly activists organisations.
} 
communities). As such several of the Indigenous interviewees worked, or had worked previously, for environmental organisations or government environmental institutions.

\section{Cape York Peninsula}

Cape York Peninsula covers an area of 14 million hectares in the far north of Queensland (Figure 1). Described as "one of the last great wild places on Earth" (Schneiders, 2006, p.6) it is under threat from mining, land clearing, and river and marine destruction. Several iconic environmental campaigns have been fought over areas in Cape York, including Starke, the McIlwraith Range and Shelburne Bay, which have resulted in the creation of National Parks predominantly on the east side of the Cape. It is a difficult region to access, with paved road ending at Laura and a monsoonal climate. It is sparsely populated with just 18,000 people in the region concentrated in a few towns and cattle stations (Ockwell and Rydin, 2006). Despite earlier forced removals from their lands, the region remains home to numerous Indigenous communities (Strang, 1997). Approximately 45\% of the population are Indigenous and many fare poorly on socio-economic measures (such as income, employment, education, health and mortality rates) (Martin, 1997). Queensland has historically been lax at acknowledging Indigenous rights and many claims against the State, such as for stolen wages, are ongoing (this is despite an offer of compensation by the State government in 2002, which was deemed inadequate and thus rejected by many Indigenous people) (Kidd, 1997).

\section{Figure 1: Cape York Peninsula, Queensland}

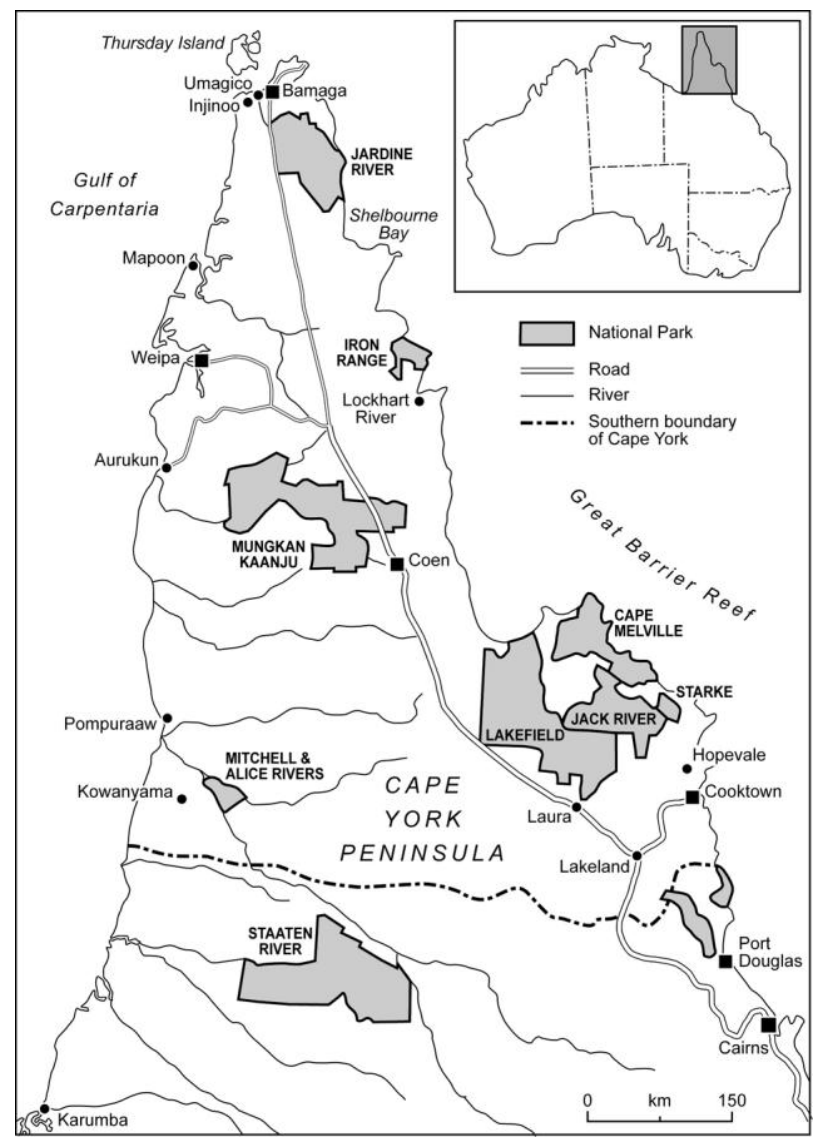

It is also a region of complex and continuously evolving land tenure where a succession of State and Commonwealth Acts have gradually increased recognition of Indigenous rights, though little is held under inalienable freehold title by Indigenous people. The result is a mix of land secured through various statutory arrangements such as Native Title determination, 
Indigenous Land Use Agreements (ILUAs), land grants, co-management arrangements, and Indigenous Protected Areas (Muller, 2003; Langton et al., 2005), or Indigenous pastoral leases. Pastoralism has been one of the most important economic activities for Indigenous people on the Cape and is "the foundation for the lived experience of the regional landscape among the senior generations of Aboriginal families across the region" (Smith, 2005, p.227). Contentiously amongst environmentalists, fire plays a key role for pastoralists who "tend to burn the land to encourage the growth of green grass for their cattle to feed on" (Ockwell and Rydin, 2006, p.385).

The construction of Cape York as a region has been both embraced by those arguing for the need for regional representation (for example by the [Indigenous] Balkanu Cape York Development Corporation) and challenged by those wishing to assert a localism and the distinctiveness of different places and communities (Martin, 1997). Moreover, interest in Cape York extends far beyond its geographical limits. Many Indigenous organisations and spokespeople for the region are located in Cairns and beyond. Several national environmental organisations have long campaigned for the protection of the Cape, including The Wilderness Society, Australian Conservation Foundation (ACF) and the World Wildlife Fund for Nature (WWF). In order to incorporate this range of interest, interviews were conducted with a broad variety of groups who had an interest in the region ${ }^{5}$.

\section{$\underline{\text { Barmah-Millewa }}$}

Barmah-Millewa is a far smaller area than the Cape at $700 \mathrm{~km}^{2}$ : a forest on the banks of the Murray (Dhungalla) river that divides northern Victoria and southern New South Wales (Figure 2) (Lacey and Ladson, 2005). Renowned for its River Red Gum forest that periodically floods producing wetlands rich in flora and fauna, it has been called "the Kakadu of the South" (VNPA, 2003, p.2). Use and ownership of the region is highly contested. It is used by Indigenous and non-Indigenous loggers, grazers, for irrigation, and for recreation (fishing and camping) (Ellemor, 2003). The region is mostly State Park and State Forest.

\footnotetext{
${ }^{5}$ Thus in Queensland interviews were undertaken with representatives of TWS, ACF, WWF, North Queensland Conservation Council (NQCC), Friends of the Earth (FOE), Cairns and Far North Environment Centre (CAFNEC), Balkanu Cape York Development Corporation, Northern Australia Environmental Alliance (NAEA), Wuthathi Tribal Council, Bamanga Bubu Ngadimunku Inc, Mossman Gorge Aboriginal Community, Indigenous Enterprise Partnerships (IEP), and North Australian Indigenous Land and Sea Management Alliance (NAILSMA).
} 


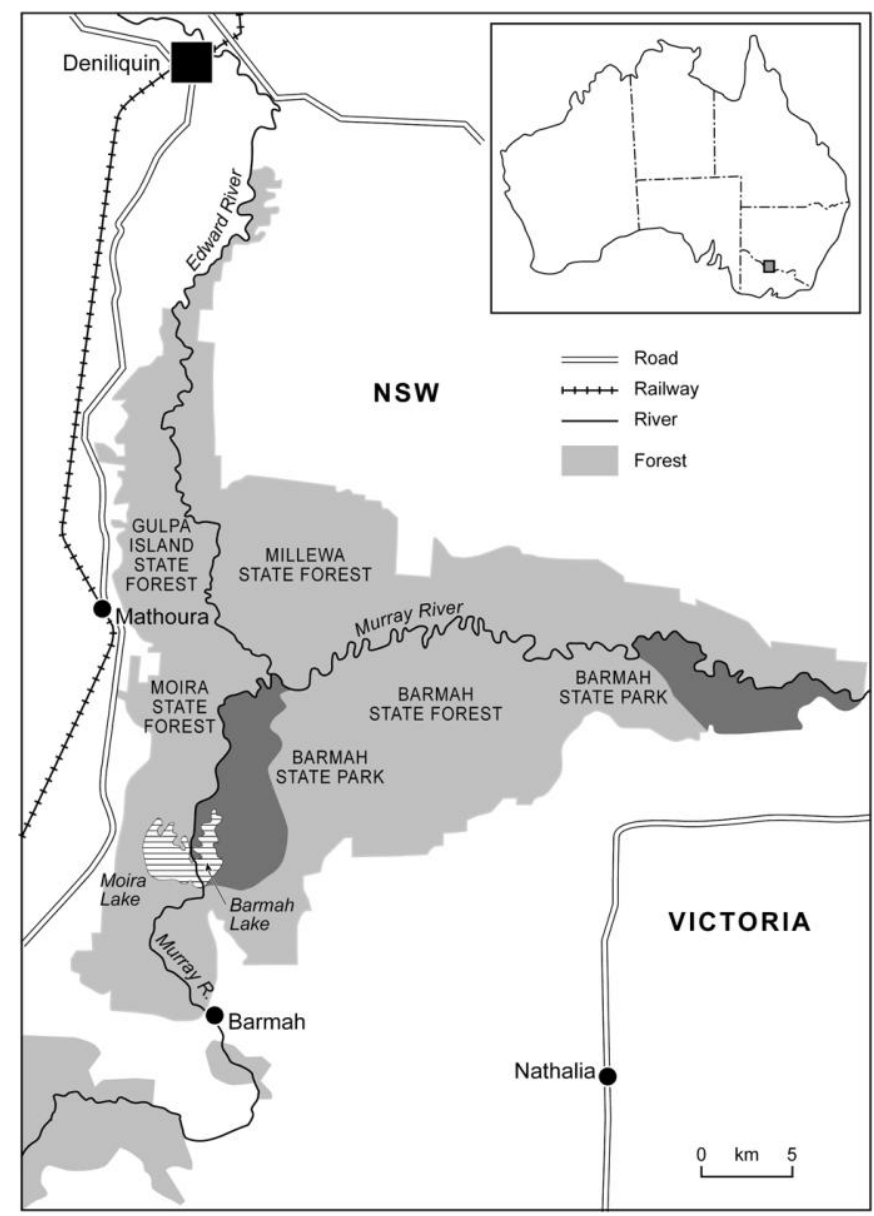

The forest is part of a broader region claimed by Yorta Yorta Traditional Owners (Atkinson, 2005a). In 1998 the Federal Court denied the Yorta Yorta Nation their Native Title claim and further appeals were denied in 2001 and 2002 (Seidel, 2004). Most controversially, Justice Olney stated in the original trial that the 'tide of history' had washed away Yorta Yorta traditional ties to the area ${ }^{6}$ (FCA, 1998). The Yorta Yorta have continued to argue their right to the land and in 2004 signed a Co-operative Land Management Agreement with Victoria State Government for the region (Atkinson, 2004). This agreement gives the Yorta Yorta an advisory role and acknowledges their cultural connection to the land, but it does not grant any direct management over the region.

Yorta Yorta have formed an alliance with environmental groups to campaign for a jointlymanaged Barmah-Millewa National Park (Atkinson, 2006). This is an unusual step for an Indigenous community but is seen as one of the few remaining options that would grant Yorta Yorta some control over their land. Moreover, it is seen as one that would provide State funding for land management and employment (Atkinson, 2005b, 2006). Notably, "the Barmah-Millewa forest campaign is the search for common ground" (Barmah-Millewa Collective, 2005) and "is about Justice for Land and People" (Friends of Earth Melbourne,

\footnotetext{
${ }^{6}$ Moreover, the case was contested by a large number of non-Indigenous stakeholders, who contested Indigenous authenticity and instead "are 'Aboriginalizing' their own attachments to place" (Ellemor, 2003, p.239).
} 
2005). Interviews were undertaken with representatives of groups taking part in the alliance ${ }^{7}$. In February 2007 a number of Indigenous organisations (including the Yorta Yorta as part of an Indigenous alliance MLDRIN - Murray and Lower Darling Rivers Indigenous Nations) formalised a cooperation agreement with an alliance of environmental groups (including TWS, FOE, ACF, and Victorian National Parks Association) to protect (ecologically and culturally) a large area of the Murray-Lower Darling Country which included the BarmahMillewa forest (TWS, 2007b).

\section{Spaces of dialogue and working practices}

Using these two case studies we can unpack the practices and mutual processes of finding common ground. The background to all of these dialogues is a long and often contested history of interactions. Interviewees invoked memories of iconic campaigns at Coronation Hill (NT), Jabiluka (NT), and Starke (Queensland) as both inspirational and problematic (see Toyne, 1994). Most acknowledged that such collaborations had been more difficult and fractured than they had hoped and there were still many lessons to be learnt about Indigenous/non-Indigenous alliances. These lessons are now explored through examining four issues that have proved contentious in finding common ground: language; power and ownership; scale and timeframes, and economics.

\section{$\underline{\text { Language and values }}$}

The language being used by non-Indigenous activists remains problematic, particularly use of the word 'wilderness' (see Figure 3) (Pickerill, 2008). It harks back to the days when Indigenous people were treated "just like the birds and the animals, and a few years ago we were living under ... the Flora and Fauna Act, so we were part of that" (Jim Davis, Caring for Country Unit Project Manager, Balkanu Cape York Development Corporation, Cairns, interview).

\footnotetext{
${ }^{7}$ Victoria National Parks Association (VNPA), FOE Melbourne, Yorta Yorta Nation Aboriginal Corporation, Environment Victoria, Goulburn Valley Environment Group, ACF, and Barmah-Millewa Collective.
} 


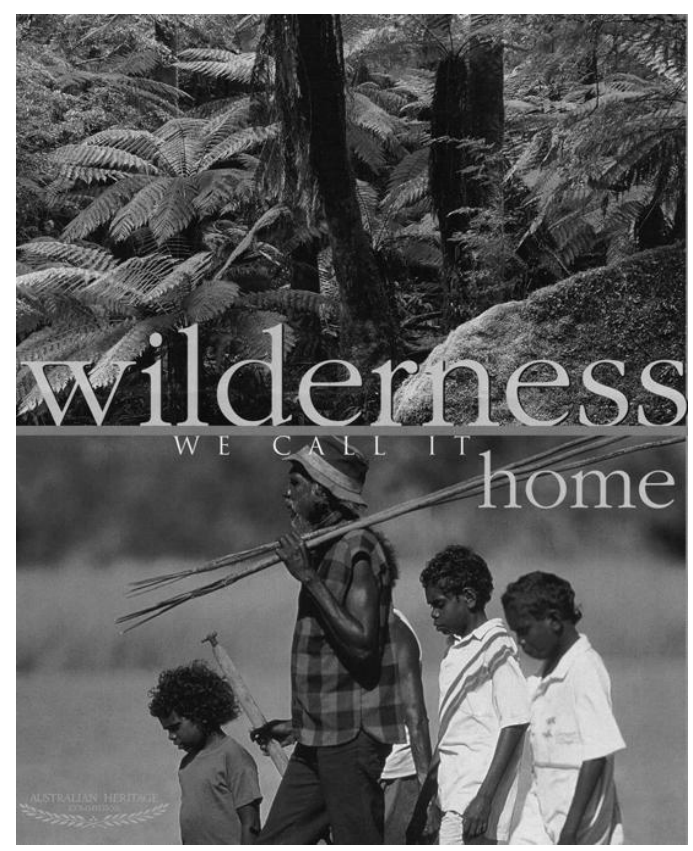

Moreover, "nobody acknowledges the cultural domain as one that's credible" (Jacqui Katona, former executive officer of the Gundjehmi Aboriginal Corporation ${ }^{8}$, Brisbane, interview). Although many non-Indigenous activists seemed to respect that for Indigenous activists the cultural domain was intertwined with the environment, non-Indigenous activists did not adopt it. Most of the Australian environmental organisations still value science as the mechanism through which to prioritise areas for environmental protection, thus undermining understandings of the cultural significance of land. TWS has in recent years extended its areas of interest to include larger swathes of Australia (as part of its WildCountry programme), incorporating desert and bush land along with its traditional areas of concern - old growth forests and rivers (Figure 4). Its reasoning, however, has more to do with science and the belief that small disjointed pockets of protected areas are inadequate for sustained environmental preservation, than an adoption of different ways of valuing land ${ }^{9}$, and they remain accused of prioritising iconic landscapes over other less visibly valuable environments.

\footnotetext{
${ }^{8}$ An organisation established, managed and controlled by the Mirrar people

${ }^{9}$ TWS contest this point. Anthony Esposito (National Manager - Indigenous Conservation Program, TWS) argues that TWS are increasingly identifying Indigenous environmental goals, knowledge and values within WildCountry scientific approaches.
} 
Figure 4: Areas of priority for The Wilderness Society WildCountry programme (adapted from The Wilderness Society)

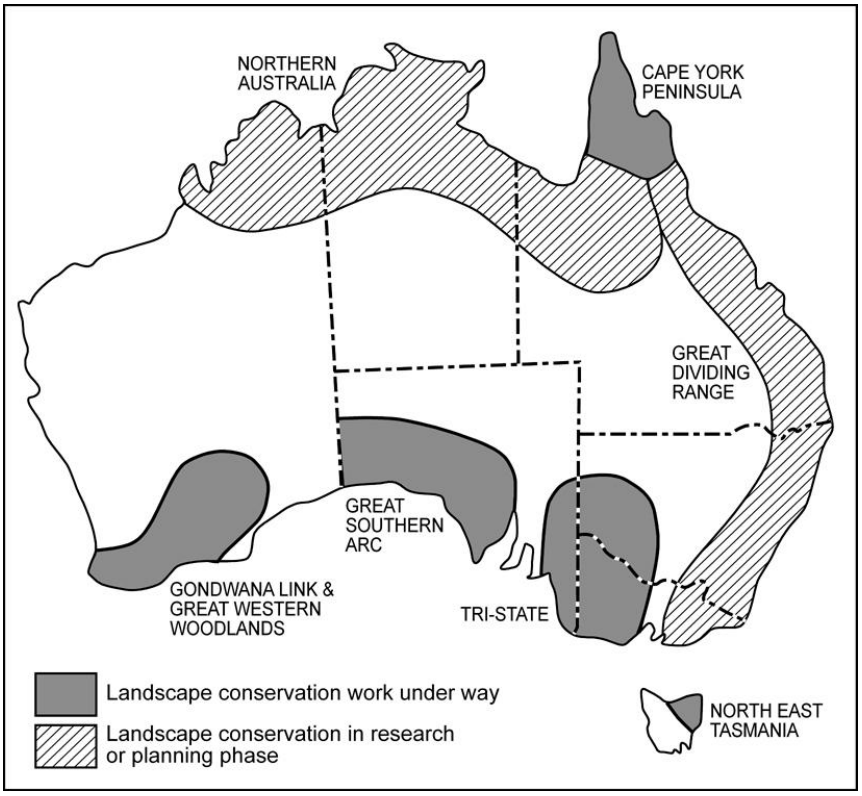

Core to the contention around use of language and values is the issue of people being on country. For Indigenous activists it is their right and responsibility to live on country and it is only through doing so that they can look after the land; "the way to look after country is not by keeping Indigenous people off it, but to allow them to go back and interact with that country so that proper biodiversity is maintained" (Arnold Wallis, Chairperson of the Wuthathi Tribal Council and ex-ACF Indigenous Liaison Officer, Cairns, interview). Attempts to prevent this by environmental groups are, not surprisingly, given the history of dispossession in Australia, met with accusations of neo-colonialism.

For non-Indigenous activists, articulating their desires for environmental protection without sounding racist has been difficult. Most sought to avoid a romantic view of Indigenous people as innately good environmentalists by acknowledging the dynamic, contemporary and fluid nature of Indigenous identity. However, non-Indigenous activists gave qualified support to Indigenous peoples' return to land only if they shared views on environmental management. The form of this commitment varied considerably across the environmental organisations; the ACF gave heavy precedence to Indigenous views of what constituted environmental protection; "ACF as a whole is really trying to put people back into the centre of our work" (Rosemary Hill, Northern Australia Programme Coordinator, ACF, Cairns, interview), whereas Queensland Conservation felt such a commitment should exclude hunting and the use of fire.

\section{$\underline{\text { Control, power and ownership }}$}

Any dialogue across difference has to acknowledge the unequal symbolic and economic power relations at play. Acknowledging these inequalities is necessary to avoid any unconscious "subsumption into a common ontology" (Johnson et al., 2007, p.118). The politics of power and ownership were most acutely expressed through the mistrust between activists as to the ultimate control over different places of environmental importance, "this is embedded in the Australian psyche - that Aboriginal people are going to lock up the land, lock up the resources" (Katona, interview) and thus restrict non-Indigenous access. However, 
"rights and interests in land are treated as living and changing, open and adapting" (Palmer, 2006, p.37) by Indigenous Australians such that "Indigenous political boundaries do not seek a closed society" (p.37). In practice there are multiple layers of ownership and rights over places in Australia where neither Indigenous inalienable control nor robust environmental protection (even National Parks contain exemptions) is legally possible, and it is in this context that commonality is sought.

Land ownership and land rights are so complicated and so emotive that the issue of who controls land is core to any alliance and yet simultaneously many activists wished to jump beyond the issue in negotiations. In Victoria, having failed to get Native Title, the Yorta Yorta are seeking jointly-managed National Park status, partly because they see it is their only option to gain some management control over their lands. However, in Cape York the quest for protected areas has been softened to accommodate multiple methods of ownership and land management. Thus non-Indigenous activists have supported Indigenous ownership of land in the form of ILUAs (where Indigenous land is co-managed with the government as a protected area) and, more recently, the Indigenous-owned freehold and controlled Indigenous Protected Areas (IPAs); "Aboriginal land, owned and managed by Aboriginal people for conservation purpose" (Anthony Esposito, National Manager - Indigenous Conservation Program, TWS, Brisbane, interview) (see Langton et al., 2005 for an evaluation of the potential of IPA's for Indigenous people). Thus TWS believe they have developed a "tenureblind approach to management" (Kerryn O'Conor, North Queensland Campaigner, TWS, Cairns, interview). This is "not about trying to secure a particular area in the form of a protected area, it's about trying to put in place a management framework that allows particular land development to occur but doesn't allow other development to occur" (ibid), which concurs with Davis' view that "the issues of tenures are false boundaries" (interview). In recent months, however, TWS activities on Cape York have come under attack from a new Indigenous group - Indigenous Environment Foundation (IEP) (Marks, 2007). IEP argue that TWS' tenure-blind approach has still excluded Indigenous people because the success of protection around the 'Wild Rivers' of the region, for example, has prevented Indigenous development of the area (IEP, 2008).

The majority of environmental groups had a clear statement or policy that defined their theoretical approach towards Indigenous rights, all requiring a commitment to the environment ${ }^{10}$. Only NQCC has abandoned direct collaboration with Indigenous activists, having felt 'sold-out' by Indigenous negotiations with adversaries in previous campaigns, "We've got our own wars to fight ... the 'Indigenous' is a side issue in that main game" (James McLellan, Co-ordinator of NQCC, Townsville, interview). TWS "reserves the right to continue to campaign ... if, after detailed consultation and discussion, Indigenous peoples do not support the protection of wilderness, protected areas and biodiversity" (The Wilderness Society, 2007a), whereas FOE "do treaties with local people to recognise them as the sovereign land owners" (Cam Walker, FOE, Melbourne, interview). ACF sought to become a bi-cultural organisation. This is a long-term shift that began with the Northern Australia Programme and the employment of Indigenous Policy Officers. Its aims include jointly deciding goals and consequently they have even sided with Traditional Owners against the creation of new National Parks. Indigenous activists did not work with those who did not respect their cultural needs ("another form of cultural genocide [is] happening at the

\footnotetext{
${ }^{10}$ For example, TWS made clear that they were not an Indigenous advocacy organisation and did not support the return of Indigenous people to land per se.
} 
environmental management level" [Wallis, interview]), nor with those who treated them merely as stakeholders which failed to consider their distinctive claims to places.

Issues of mistrust were only overcome by all parties being explicit about their intentions and interests, which many groups at first failed to do; "we have got to put them on the table and be up front about it and be honest if there is going to be some issues here that we are going to clash over. But I don't think that has happened in the past" (Joe Morrison, Co-ordinator of NAILSMA, Darwin, interview). Core to these discussions, of course, was that the right people were talking to each other and non-Indigenous activists have in the past made mistakes in the protocol of whom they spoke to; "you will have members who will pretty much speak on all and every issue but it doesn't work like that" (Eddie Barney, Chairman of Mossman Gorge Aboriginal Community, Mossman Gorge, interview), though many noted the complexity of trying to determine who to talk to, "you go to the Land Council and visit 18 mobs ${ }^{11}$ and then all their clan groups" (Nicky Hungerford, Campaigner, CAFNEC, Cairns, interview). Just as elsewhere, personality politics play an important role here too.

Even when, however, good dialogue occurred between activists at a grassroots level some non-Indigenous activists struggled to convince those higher up in their organisations to value Indigenous engagement and to make any concessions in their campaigning. Activists from TWS, ACF, VNPA, CAFNEC and WWF all recognised that their organisations suffered a form of institutional colonialism that would take many years to shift. At ACF internal "debates exposed views that had very little understanding and engagement of Indigenous issues" (Don Henry, Executive Director, ACF, Melbourne, interview). This was compounded by a perception by some that environmental groups only needed to engage with Indigenous politics in northern Australia. In reality, most groups, while acknowledging that "our level of engagement and our insights on Indigenous issues has been uneven" (Henry, interview), had long dealt with Indigenous politics in the south. For many years an ACF Indigenous policy officer was based in Melbourne (albeit only ever one or two posts), FOE worked with Indigenous groups in Victoria, and TWS has recently expanded its programme "into two new cooperation agreements with southern Australian Indigenous organisations" (Esposito, personal communication). Nevertheless, Indigenous activists feared,

a lack of understanding from people who are mainly down south where the big voting populations are, and they would be much more receptive to the arguments of the greens, to protect dugong, to protect turtle, to protect wilderness. ... It's much more difficult for us to come out and say 'we hunt, we exploit country, we earn about $\$ 180$ a week on the $\mathrm{CDEP}^{12}$, - we can do it, but people would not be as receptive ... they just conceptually can't understand it. (Davis, interview)

\footnotetext{
${ }^{11}$ The term 'mob' is Australian slang for a group of people (often friends or family). It does not denote trouble and is used to describe Indigenous and non-Indigenous groups.

${ }^{12}$ Community Development Employment Projects (CDEP) is a government-funded program for unemployed Indigenous people in certain locations in Australia. It began in May 1977 for some remote Indigenous communities as a way to provide state help without offering unemployment payments, which it was feared, might encourage social problems. It works through funding CDEP organisations who provide employment and training to participants. It has been criticised as being 'sit-down' money that hinders the creation of real employment opportunities and creates a poverty trap. However, "CDEP employs around 36,000 Indigenous Australians and accounts for over one-quarter of total Indigenous employment and 63 per cent of Indigenous employment in remote areas" (Altman and Gray, 2005, p.400) and Altman and Gray have proved it to be a success by several measures.
} 
This inequity in being able to mobilise supporters illustrates the uneven capacity of activists in what they bring to negotiations. Indigenous activists can suffer from a lack of resources, something environmental groups have provided, "WWF offers the ability to build capacity, to bring resources" (Russell Kelly, Australia Senior Programme Officer, WWF, Brisbane, interview). Although these are often "not so much direct resources" (Lyndon Schneiders, Cape York and Far-North Australia Campaigner, TWS, Brisbane, interview) but more "a bit of practical solidarity. Resourcing is more with ideas and networking and value-adding and providing more specific technical information and capacity" (Dave Sweeney, Nuclear Campaigner, ACF, Melbourne, interview). In particular Indigenous activists talked of the value of gaining scientific knowledge from environmental groups, especially given that many environmental problems have been imported, "we need to understand a bit more of the science of this - the western science of it, even though I know we got a lot of traditional knowledge" (Noel Gertz, former Project Officer, Burdekin Dry Tropics Board, Townsville, interview). Others saw a need to support Indigenous activists in becoming organised, "there's a lot of traditional owners out there who are upset at what's happening on their land, but they're not necessarily highly organised ... so there's a lot more support work in terms of actually working with Traditional Owners, in terms of capacity building for the ability to run campaigns" (Jonathan La Nauze, FOE Melbourne, Melbourne, interview). For Michael Winer (Chief Executive Officer and one of the founders of Indigenous Enterprise Partnerships, Cairns) this contribution to Indigenous capacity should be without strings and facilitate Indigenous leadership;

our Indigenous partners didn't have access to the sort of knowledge, resources and so forth to make well-informed equal decisions ... the environment movement was naively, or ignorantly, utilising that power imbalance - and the power being wealth, knowledge, access to networks and resources - to lever outcomes that weren't in the interests of the Indigenous people. I felt quite strongly that the environment movement as a whole were no better than the mining companies with cases of beer under their hands ... what they need to do is simply support Indigenous environment initiatives ... go and fund raise and fund the Land and Sea Management Centres around the Cape - you'll get a much bigger outcome. Assign your people into the Aboriginal organisations to work for them. Stop empire building ... trust people that they can do their own land management and give them the money and resources to do it, rather than building your own coffers and your own power base. (interview)

However, politically Indigenous activists may have the greater power to leverage for conservation outcomes, thus "who cares if we talk to the greenies or not because they're not in any position of power" (Katona, interview). In reality, few have had the ear of a Liberal government (though many are more optimistic since the election of the Labor Federal government in December 2007 and Rudd's apology to Indigenous people in February 2008), but the perception remains that "the Aboriginal people are becoming more aware of what political clout they actually have now in Australia, through legislation and the different acts I think that's attracted more resources ... whereas volunteer organisations still have to go out in the koala bear suits with their bucket every Friday night" (Cliff Cobbo, Aboriginal Land Management Facilitator, Burdekin Dry Tropics Board, Townsville, interview).

Given this unevenness in power and capacity, and that "black politics are so complicated and so difficult ... constantly changing" (Hungerford, interview), coupled with limits to how 
much non-Indigenous people are allowed to know of sacred and cultural sites, many nonIndigenous groups have sought 'middle people'; "There's usually someone in whichever community we work with who straddles both worlds. If you don't have that, I'd actually argue that cultural difference is so huge that it's almost impossible to have a deep working relationship" (Schneiders, interview). These working relationships are reliant upon good communication supported by agreed protocols. Crucial to this communication is acknowledging that "we need to make sure that we change ... we have to actually go out and work within their realms because they have been stuffed around so many years by various groups and various agencies" (Nick Roberts, VNPA, Melbourne, interview). Overall,

\begin{abstract}
there needs to be very clear and very deliverable expectations ... Face-to-face communication is key - very hard to have strong Indigenous relationships remotely ... Delivering on what you say you're going to do is very important ... Flexibility and to respect that Indigenous people have different priorities and different needs ... Indigenous leadership is pivotal. (Sweeney, interview)
\end{abstract}

What is clear in these exchanges is that although concessions are made between Indigenous and non-Indigenous activists and control conceded on some issues (such as land ownership), all activists wanted to retain leadership. Most activists acknowledged that equality between Indigenous and non-Indigenous interests was impossible, "one group or another has to subsume its own interests" (Schneiders, interview), and as there was not enough trust that there were shared objectives, groups rarely conceded power. This is not the same as suggesting everyone is in an equal position of power, but that not surprisingly no one wants to concede what little power they have. Dialogue was thus a negotiation weaving between the different capacities, resources and power each group brought to the table. Thus for Indigenous activists "it's about us maintaining control of the agenda" (Davis, interview) and for nonIndigenous, "I have a right as a greenie, I have to respect you and I can talk it through ... but I still have the right to say if I think it's wrong" (Hungerford, interview).

Indigenous activists are aware of their political voices (and resources) and are prepared to use them, just as non-Indigenous activists may be willing to override certain Indigenous objections to environmental projects. However, all know that they need each other in different ways for different ends; "working with Aboriginal people was the only way that we're going to get conservation outcomes" (Crase, interview) and "everyone's realised that we each have the potential to block each other, but we also have the potential to help each other" (Esposito, interview).

\title{
$\underline{\text { Scale and timeframes }}$
}

This lack of trust that prevents activists conceding the ultimate power of leadership is due in part to the different timeframes and scale at which activists work. Sweeney notes activists need "a three $\mathrm{T}$ formula for working with Aboriginal people, which is Talk, Time and Trust and you only get the third by the combination of the first two" (interview). Relationships between Indigenous and non-Indigenous activists take a considerable time to build, "the relationships that have really worked, have ended up being quite long term relationships ... it's about people to people relationships" (Schneiders, interview). Many non-Indigenous activists felt they lacked the time necessary to do this and the problem was compounded by a high staff turnover within their organisations. For Indigenous activists there was a sense that "you hear from the environmental groups when they want support to stop something happening ... but we're still here in between all those other issues" (Damian Britnell, Chief 
Executive Officer, Bamanga Bubu Ngadimunku Inc ${ }^{13}$, Mossman Gorge, interview). In response ACF developed a programme (rather than a campaign) that deliberately attempted to build a long-term partnership with different Indigenous organisations and communities.

Key to this approach was a downshift in scale. After many years of negotiation, TWS, ACF, CAFNEC, many Indigenous representatives and pastoralists signed the Cape York Heads of Agreement (1996) - a formal and groundbreaking agreement on environmental management on the Cape. Although it has served well as a moment of commonality, eventually it fell apart and this was in part due to its regional scale, "talking to people on the ground, particularly at the Traditional Owner level, there's a lot of support for conservation outcomes, but when you draw back from that and you get involved in the more regional politics, that's when it starts getting murky and difficult" (O’Conor, interview). Thus,

The scale that Aboriginal communities work on is closer than local ... you've got to source or direct orally authentic relationships, which really exist at the local level in an unorganised way still. The fact that there are organisations called Aboriginal organisations doesn't mean that they necessarily represent the interests of Aboriginal people they tend to represent the interests of the survival of the organisation. (Katona, interview)

Consequently TWS began to shift towards more grounded community level cooperation. WWF also focused on small-scale practical community projects (such as turtle care programmes) in apparent collaboration with Indigenous needs, but crucially their scale enabled WWF to ignore debates about cultural identity and postcolonialism, "a lot of the ... smaller NGO environment groups do have pretty good reputations where they have been working with people for an extended period of time. Some of the larger groups I think it is a different kettle of fish" (Morrison, interview). In Victoria, part of the success of the BarmahMillewa alliance was its relative small scale.

Agius et al. (2002) have explored the issue of scale in relation to Native Title negotiations in South Australia and note that although it is important that local issues are dealt with locally, the most important aspect of scale is that it is determined by Indigenous people. Thus by subverting non-Indigenous structures "a new scale of Indigenous self-governance at the whole-of-state scale" (p.11) was also established by the people themselves and which consequently enabled them to have a strong negotiating relationship with the State. Thus "new scales of coexistence" (Howitt, 2006, p.64) are developed which are not imposed from above, but are neither necessarily constrained to the local. This necessity to grapple with the scaled politics of Indigenous groups, not just reduce scale to the local, has yet to be fully tackled by non-Indigenous groups. There are some signs of success, such as the new cooperation agreement with MLDRIN in Victoria - an equal partnership at a regional scale but much work is still to be done.

\section{$\underline{\text { Economic issues }}$}

All activists identified resolving economic problems as key to environmental issues, both because "their social problems far outweigh their environmental concerns" (McLellan, interview) and because many of the environmental issues, such as the pressure to build cattle

13 The corporation of Mossman Gorge Aboriginal Community 
feedlots on the Cape, were driven by the economic concerns of Indigenous pastoralists. TWS developed a conservation economy approach, which explored alternative income opportunities such as eco-tourism, and the emerging carbon and natural resource management economies, to replace the current reliance on mining, cattle, and government welfare, "what we need is more development in the economic sphere so that we can prove that there is a different development pathway" (Esposito, interview). ACF developed an alternative economics framework that sought to use welfare money to more clearly support land management, "so that people are not just getting sit-down money, they're getting support through the things they actually want to do, which we know caring for country is one of those things people really want to do, and have done against great odds" (Hill, interview). Although acknowledged by Indigenous activists as a step in the right direction, some of their ideas were still seen as paternal "because it's their ideas, it's their perceptions of what would be good for people, it is their perceptions of how to fix problems" (Winer, interview).

However, despite this engagement with economic issues, non-Indigenous activists tried to avoid dealing with the contentious issue of hunting. In Queensland most controversy surrounds the hunting of marine animals (see Havemann et al., 2005), "there's an attitudinal shift that needs to happen ... a greater appreciation that people ... do rely on the resources that country provides to live and to practise their [Indigenous] cultural rights and some of those things include the hunting of threatened species like turtle and dugong" (Davis, interview). TWS remained quiet on the issue; however simultaneously in Western Australia dugongs were used very symbolically in the TWS-led Save Ningaloo campaign (Figure 5) illustrating the conflicted attitude within the organization.

Figure 5: Use of the dugong as a symbol in the Save Ningaloo campaign, 2002 (Source: The Wilderness Society)

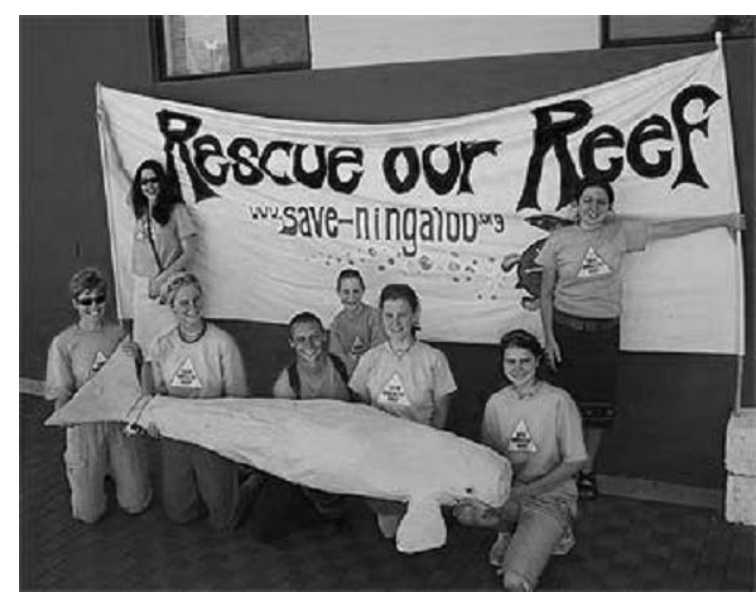

The issue of hunting is avoided because it would require debate as to Indigenous rights, something non-Indigenous activists are careful to skirt, but it is also about a lack of trust that Indigenous people understand how to manage land and sea resources, which is contested by many Indigenous activists, "our own people do hunt, but we have some understanding in the mob about why we're hunting and it's mainly for ceremony, we make sure we don't hunt female sea cows, dugong" (Wallis, interview). 


\section{Conclusions}

Defining a politics that can bridge the multiple heterogeneities, including most emphatically those of geography, without repressing difference, is one of the biggest challenges of the twenty-first century. (Harvey, 1996, p.438)

This paper has used interactions between Indigenous and non-Indigenous activists around environmental issues to better understand how commonality across difference is negotiated. It fills a gap in the existing work on common ground that is dominated by explorations of formal processes of agreement by focusing on the informal spaces of activism. It illustrates the importance of debates around country and environment in moving towards a postcolonial nation, and the moments of opportunity to share and understand different ontologies in creating a "space for Indigenous ways of being-in-place" (Howitt and Suchet-Pearson, 2006, p.329).

This micro scale examination of the spaces of dialogue and working practices between Indigenous and non-Indigenous activists has illustrated the sheer number of issues (social, economic, legal, institutional, emotive, and scientific) that can form both barriers and opportunities in finding common ground. Activists had mixed success in putting their intentions into practice. Many non-Indigenous activists had adopted protocols, changed meeting practices, altered language, and re-prioritised campaigns to reflect an understanding of Indigenous concerns. However, the need for a pluralistic and agonistic politics was well understood by Indigenous and non-Indigenous activists. No one assumed that there would necessarily be any common ground between them (many acknowledged their multiple differences), nor that it was always necessary to compromise to determine a common good; "if you're not going to withdraw then you have to be able to find ways of communicating and working together that allows disagreements, and not to try and load that too much up with too much angst and hand wringing" (Schneiders, interview).

However, the success or failure of these dialogues is in part determined by how the two boundaries of difference around place and environment were negotiated by all parties. First, that place was important, and Indigenous ownership and access to land was a non-negotiable demand of many Indigenous activists, was eventually accepted by most non-Indigenous activists, especially in Queensland. While they may not have conceded the power of leadership, non-Indigenous activists have finally begun to acknowledge that Indigenous ownership of land is not as much of a threat to its environmental protection as they may have previously believed. Moreover, some non-Indigenous activists have come to see that living on country is a necessary part of good land management. There is no doubt that there is still dissent within environmental organisations, and its acceptance is tempered by a continuing tendency to value place through scientific determinations of conservation value. However, that discussions are finally moving beyond issues of tenure is a significant sign of hope.

Second, non-Indigenous activists knew and understood their own contradictions of dualistic thinking about environment-society relations, but felt limited in developing ways which could break down the conceptual boundaries between society and environment without undermining their own environmental and campaigning rationale. Thus there remained an institutional colonial barrier to broader shifts in practices for many organisations. Many non-Indigenous activists retained a view of the 'environment' as separate from any consideration of the 'cultural', devaluing the Indigenous emphasis on the importance of interdependence. Some 
non-Indigenous activists struggled with the risks of reading responsibility for Indigenous issues as a new form of colonialism. All activists sought to unpack what mutual responsibility would look like and fought practices that further increased the dependency of Indigenous on the non-Indigenous. Although a mine-field of potential misunderstandings, activists were building long-term relationships that enabled more honest discussion about these many complexities, and very gradually were beginning to create links of trust. Key to these dialogues were the 'middle people' who acted as contacts between Indigenous and nonIndigenous activists. The role of such 'middle people' requires further research and could be an important contribution to understanding how the two worlds navigate each other.

Overall, though there are ongoing problematic practices there is a growing mutual ownership of the issues and it is in the acceptance of the complexity of these dynamics where hope springs. Moving beyond a colonial paternal sense of responsibility, to a dynamic and engaged mutuality of concern for both processes and outcomes has resulted in gradual, small and progressive steps forward. More than anything, these processes illustrate the accomplishments possible if we take the time and care to listen to each other more intently; "The better the dialogue, the levels of understanding, the levels of respect, the consistency and behaviour, and the early work to frame futures that genuinely do deliver good social, economic and environment outcomes, the better off we'll all be" (Henry, interview).

\section{Acknowledgements}

This research was undertaken through funding provided by The British Academy (SG-38399). I am also grateful for space, facilities and intellectual support provided by the School of Indigenous Australian Studies at James Cook University (Townsville and Cairns) and the School of Anthropology, Geography \& Environmental Studies at Melbourne University. Thanks too for constructive comments on earlier versions of this paper by participants at a seminar at the Department of Geography, Liverpool University and at a Postcolonial Series seminar, Leicester University. Particular thanks go to the anonymous referees who helped reshape the paper into a clear form. Thanks also to Ruth Pollington for her map-making skills. This paper would not have been possible without the invaluable help of all the interviewees.

\section{References}

Adams, M., 2004. Negotiating nature: collaboration and conflict between Aboriginal and consservation interests in New South Wales, Australia. Australian Journal of Environmental Education, 20; 3-11.

Adams, W, M and Milligan, M., 2003. Introduction in W.M.Adams and M.Mulligan (Eds) Decolonizing Nature: Strategies for conservation in a Post-Colonial Era. Earthscan, London, p. 1-16.

Agius, P., J. Davies, R. Howitt and L.Johns. 2002. "Negotiating Comprehensive Settlement of Native Title Issues: building a new scale of justice in South Australia." Land, Rights, Laws: Issues of Native Title 2(20): 1-12. [available online at http://ntru.aiatsis.gov.au/ntpapers/IP20v2.pdf]

Agius, P., T. Jenkin, S. Jarvis, R. Howitt, and R. Williams. 2007. "(Re)asserting Indigenous Rights and Jurisdictions within a Politics of Place: Transformative Nature of Native Title Negotiations in South Australia." Geographical Research 45(2): 194-202.

AIATSIS, 2000. Guidelines for Ethical Research in Indigenous Studies. The Australian Institute of Aboriginal and Torres Strait Islander Studies, www.aiatsis.gov.au/_data/assets/pdf_file/2290/ethics_guidelines.pdf 
Altman, J and M. Gray. 2005. The economic and social impacts of the CDEP scheme in remote Australia (Community Development Employment Projects), Australian Journal of Social Issues, 40 (3) 399-411

Atkinson, H., 2004. Yorta Yorta Co-operative Land Management Agreement. Native Title Newsletter, 4, 6-8.

Atkinson, W., 2005a. Yorta Yorta Occupation and 'the search for common ground'. Proceedings of the Royal Society of Victoria, 117 (1), 1-22.

Atkinson, W., 2005b. Personal communication, $1^{\text {st }}$ September.

Atkinson, W., 2006. Balancing the scales of Indigenous land justice in Victoria, Australia. Seminar, Leicester University, $30^{\text {th }}$ March.

Baker, R, Davies, J and Young, E., 2001. Introduction in R.Baker, J.Davies and E. Young (Eds.) Working on Country: Contemporary Indigenous Management of Australia's Lands and Coastal Regions. Oxford; Oxford University Press, p.xxi-xxiv.

Barmah-Millewa Collective., 2005. Along the Murray River is the world's largest remaining stand of river red gum. Campaign flyer.

Beck, U., 2006. The Cosmopolitan Vision. Polity Press, Cambridge.

Blaut, J, M., 1993. The Colonizer's Model of the World: Geographical Diffusionism and Eurocentric History. Guilford Press, New York.

Castree, N and Head, L., 2007. Culture, nature and landscape in the Australian region. Geoforum

Castree, N., 2004. 'Differential geographies: place, Indigenous rights and 'local' resources' Political Geography, 23, 133-167

Cresswell, T., 2004. Place: A Short Introduction. Blackwell, Oxford.

Davison, A. forthcoming. The trouble with nature: Ambivalence in the lives of urban Australian environmentalists. Geoforum.

Department of the Environment, Water, Heritage and the Arts,. 2008. Guide to the EPBC Act, www.environment.gov.au/epbc/publications/pubs/epbc-act-guide.pdf, $\quad$ accessed 19.02 .08

Dobson, P., 1997. Finding Common Ground. Habitat Australia (ACF magazine), April

Ellemor, H., 2003. White skin, black heart? The politics of belonging and Native Title in Australia. Social and Cultural Geography, 4 (2), 233-252.

Escobar, A., 2001. 'Culture sits in places' Political Geography, 20 (1), 139-174

FCA (Federal Court of Australia)., 1998. The Members of the Yorta Yorta Aboriginal Community v The State of Victoria and Others, no. 1606, 18 December.

Gelder, K and Jacobs, J, M., 1998. Uncanny Australia: Sacredness and Identity in a Postcolonial Nation. Melbourne University Press, Melbourne.

Gilmartin, M., 2002. 'Making space for personal journeys' in P.J.Moss (ed.) Feminist Geography in Practice: Research and Methods. Blackwell, Oxford.

Gooder, H and Jacobs, J, M., 2000. ''On the border of the unsayable' The Apology in Postcolonizing Australia' Interventions: International Journal of Postcolonial Studies, 2 (2), 230-247.

Gregory, D., 2001. Post-colonialism. In Johnston, R., Gregory, D., Pratt, G. and Watts, M., (eds) The Dictionary of Human Geography. Blackwell, Oxford, 612-615.

Hannerz, U., 1996. Transnational Connections: Cultures, People, Places. Routledge, London

Harvey, D., 1996. Justice, nature and the geography of difference. Blackwell, Oxford.

Havemann, P, Thiriet, D, Marsh, H and Jones, C., 2005. Traditional use of marine resources agreements and dugong hunting in the Great Barrier Reef World Heritage Area, Environmental and Planning Law, 22; 258-280.

Held, D., 1995. Democracy and the Global Order: From the Modern State to Cosmopolitan Governance. Polity, Cambridge. 
Howitt, R and Suchet-Pearson, S., 2006. Rethinking the building blocks: ontological pluralism and the idea of 'management'. Geografiska Annaler B, 88: 323-335

Howitt, R., 2001. Rethinking Resource Management: justice, sustainability and indigenous peoples. London, Routledge.

Howitt, R., 2006. "Scales of Coexistence: Tackling the Tension Between Legal and Cultural Landscapes in Post-Mabo Australia." Macquarie Law Journal 6: 49-64.

IEP., 2008. 'The Wilderness Society are not welcome on Cape York Peninsula', Indigenous Environment Foundation, www.myspace.com/iefyouth, accessed $19^{\text {th }}$ February 2008.

Jackson, S., 1995. "The water is not empty: cross-cultural issues in conceptualising sea space." Australian Geographer 26(1): 87-96.

Jackson, S., M. Storrs, and J. Morrison., 2005. "Recognition of Aboriginal rights, interests and values in river research and management: Perspectives from northern Australia." Ecological Management \& Restoration 6(2): 105-110.

Jacobs, J M., 1996. Edge of Empire: Postcolonialism and the City. Routledge, London and New York: xiii+186pp.

Johnson, J, Cant, G, Peters, E, Howitt, R., 2007. Creating Anti-colonial Geographies: Embracing Indigenous Peoples' Knowledges and Rights. Geographical Research, 45 (2), 117-120

Johnson, J, T and Murton, B., 2007. 'Re/placing Native Science: Indigenous Voices in Contemporary Constructions of Nature' Geographical Research, 45 (2), 121-129

Kidd, R., 1997. The Way We Civilise. University of Queensland Press, Brisbane.

Lacey, G and Ladson, A, R., 2005. Barmah-Milleaw Forest: Indigenous heritage, ecological challenges. Proceedings of the Royal Society of Victoria, 117 (1), xi-xv

Langton, M, Ma Rhea, Z, and Palmer, L., 2005. Community-Oriented Protected Areas for Indigenous Peoples and Local Communities. Journal of Political Ecology, 12: 23-50

Langton, M., 1998. Burning Questions: emerging environmental issues for Indigenous peoples in northern Australia. Centre for Indigenous Natural and Cultural Resource Management, Northern Territory University, Darwin.

Langton, M., 2003. 'The "Wild", the Market, and the Native: Indigenous People Face New forms of Global Colonization', in Globalization, Globalism, Environments, and Environmentalism. Concsiousness of Connections, The Linacre Lectures, edited by S.Vertovec and D. Posey, 141-167. Oxford; Oxford University Press.

Laurie, N, Andolina, R and Radcliffe, S A., 2005. 'Ethno-development: social movements, creating experts and professionalising Indigenous knowledge in Ecuador' Antipode: Journal of Radical Geography 39 (3): 470-496

MacIntyre, A., 1998. Whose Justice? Whose Rationality? Duckworth, London

Marks, K., 2007. The Battle for Cape York. The Independent, 16 October, 22-23

Martin, D, F., 1997. Regional agreements and localism: a case study from Cape York Peninsula. Discussion Paper no.146, Centre for Aboriginal Economic Policy Research, The Australian National University.

Martin, K., 2003. Ways of Knowing, Being and Doing: A Theoretical Framework and Methods for Indigenous and Indigenist re-search. In McWilliam, Stephenson and Thompson (eds) Voices of Dissent: Journal of Australian Studies, 76, 203-14.

Massey, D., 1999. Power-geometrics and the politics of space-time. Heidelberg, University of Heidelberg

McGregor, A., 2004. 'Sustainable development and 'warm fuzzy feelings': discourse and nature within Australian environmental imaginaries Geoforum 35, 593-606.

Milton, K., 1999. Nature is already sacred. Environmental Values, 8; 437-449.

Mohan, G., 2006. 'Embedded cosmopolitanism and the politics of obligation: the Ghanaian diaspora and development' Environment and Planning A, 38, 867-883. 
Mouffe, C., 2000. The Democratic Paradox. Verso, London.

Mouffe, C., 2005. On The Political. Routledge, London.

Muller, S., 2003. "Towards Decolonisation of Australia's Protected Area Management: the Nantawarrina Indigenous Protected Area Experience." Australian Geographical Studies 41(1): 29-43.

Ockwell, D and Rydin, Y., 2006. Conflicting Discourses of Knowledge: Understanding the Policy Adoption of Pro-Burning Knowledge Claims in Cape York Peninsula, Australia. Environmental Politics, 15 (3), 379-398.

Palmer, L., 2006. 'Nature', Place and the Recognition of Indigenous Polities', Australian Geographer, 37 (1), 33-43

Parekh, B., 2003. 'Cosmopolitanism and global citizenship' Review of International Studies, 29 (3), 3-17

Passy, F., 2001. 'Political altruism and the solidarity movement, an introduction' in M.Guigni and F.Passy (eds) Political Altruism? Solidarity Movements in International Perspective. Rowman and Littlefield Publishers, Lanham, MD, pp.3-25

Peet, R and Watts, M., 1996. Liberation Ecology; Development, sustainability and environment in an age of market triumphalism, in R.Peet and M.Watts (Eds.) Liberation Ecologies: Environment, development, social movements. Routledge, London, p.1-46

Pickerill, J., 2008. From Wilderness to WildCountry: The power of language in environmental campaigns in Australia. Environmental Politics, 17 (1), 95-104

Popke, J., 2006. Geography and Ethics: Everyday Mediations through Care and Consumption. Progress in Human Geography, 30 (4): 504-512.

Porter, L., 2006. 'Rights or containment? The politics of Aboriginal cultural heritage in Victoria' Australian Geographer 37 (3):355-374.

Povinelli, E., 2002. The cunning of recognition: Indigenous alterities and the making of Australian multiculturalism. Duke University Press, London.

Rose, D, B., 1996. Nourishing Terrains: Australian Aboriginal Views of Landscape and Wilderness. Australian Heritage Commission, Canberra

Rose, D, B., 2004 Reports from a Wild Country: ethics for decolonisation. University of New South Wales Press, Sydney.

Savage, M, Bagnall, G and Longhurst, B., 2005. Globalization and Belonging. Sage, London.

Schneiders, L., 2006. 'Cape York: Protecting one of the last great wild places on earth' Wilderness News, 169, Winter, 6

Seidel, P., 2004. Native Title: The struggle for justice for the Yorta Yorta Nation. Alternative Law Journal, 29 (2), 70-74

Shaw, W, S Herman, R, D, K, Dobbs, G, R., 2006. 'Encountering Indigeneity: Re-imagining and decolonising geography' Geografiska Annaler B, 88, 267-276

Sidaway, J, D., 2000. 'Postcolonial geographies: an exploratory essay' Progress in Human Geography, 24, 591-612.

Smith L T., 1999. Decolonizing Methodologies: Research and Indigenous Peoples. University of Otago Press.

Smith, B, R., 2005. Culture, change and the ambigious resionance of tradition in Central Cape York Peninsula. In L.Taylor, G.K.Ward, G.Henderson, R.Davis and L.A.Wallis, The Power of Knowledge, the Resonance of Tradition, Aboriginal Studies Press, Canberra, pp.223-235.

Smyth, D., 2001. Management of Sea Country: Indigenous People's Use and Management of Marine Environments, in R.Baker, J.Davies and E. Young (Eds.) Working on Country: Contemporary Indigenous Management of Australia's Lands and Coastal Regions. Oxford; Oxford University Press, p.60-74 
Strang, C., 1997. Uncommon Ground: Cultural Landscapes and Environmental Values. Berg, Oxford.

The Wilderness Society (TWS)., 2007a. Indigenous Rights Policy, http://www.wilderness.org.au/campaigns/wildcountry/Indigenous/indigplcy/, accessed $24^{\text {th }}$ July 2007

The Wilderness Society (TWS)., 2007b. Press Release: Indigenous Environment Alliance formed to protect the Murray-Lower Darling Country. Htpp://www.winderness.org.au/campagns/wildcountry/indigenous/mldrin, accessed $19^{\text {th }}$ February 2008

Tomlinson, J., 2003. 'Interests and identities in cosmopolitan politics', in S.Vertotec and R.Cohen (eds) Conceiving Cosmopolitanism. Oxford University Press, Oxford.

Touraine, A., 2000. Can We Live Together? Equality and Difference. Polity Press, Cambridge.

Toyne, P. 1994. The Reluctant Nation: Environment, law and politics in Australia. ABC Books, Sydney, Australia.

VNPA (Victorian National Parks Association)., 2003. River Red Gum Forests of northern Victoria and southern New South Wales: Our Natural Heritage. Campaign flyer

Walton, B, K and C. Bailey. 2005. Framing Wilderness: Populism and Cultural Heritage as Organizing Principles. Society and Natural Resources, 18; 119-134.

Willems-Braun, Bruce. 1997. Buried Epistemologies: The Politics of Nature in (Post)colonial British Columbia. Annals of the Association of American Geographers 87 (1):3-31.

Young, E, Ross, H, Johnson, J and Kesteven, J., 1991. Caring for Country: Aborigines and Land Management. Australian National Parks and Wildlife Service, Canberra 